Механізм впровадження системи контролінгу на вітчизняних підприємствах надасть можливість продукувати ефективні управлінські рішення щодо підвищення рівня їх конкурентоспроможності.

$$
\text { Висновки. У сучасних умовах }
$$

господарювання на вітчизняних підприємствах недоліком є відсутність інформації про поточний стан i про перспективи їх діяльності, які потребують ефективного формування нових підходів до управління. Впровадження системи контролінгу на вітчизняних підприємствах надасть можливість досягти успіхів i визнання на вітчизняному та світовому ринках, за рахунок продукування ефективних управлінських рішень. Механізм впровадження системи контролінгу на вітчизняних підприємствах включає в себе оцінку: об'єктивних факторів впровадження контролінгу; інструментів контролінгу; етапів впровадження контролінгу.

\section{СПИСОК ЛІТЕРАТУРИ}

1. Балацкий Е.О. Фінансові потоки у глобальному світі // Механізм регулювання економіки, міжнародний науковий журнал, № 3, т. 1 (35), 2008. - Суми: Університетська книга - С. $173-180$.

2. Веклич О. О. Економічний механізм регулювання контролінгу в Україні / О. Веклич. К.: 2003. -88 c.

3. Давидович I.Є. Контролінг: Навчальний посібник. / I.Є. Давидович. - К.: Центр учбової літератури, 2008. - 552 с.
4. Калайтан Т.В. Контролінг: Навчальний посібник./ Т.В. Калайтан. - Львів: Новий Світ2000, 2008. - 252 c.

5. Портна О. В. Контролінг: навч. посібник / О. В. Портна. - Львів: Магнолія 2006, 2009. $-262 \mathrm{c}$.

6. Пушкар М. Контролінг: Монографія/ М. Пушкар, Р. Пушкар,; М-во освіти і науки України , Терноп. академія народ. господ.. Тернопіль: Карт-бланш, 2004. - 370 с.

7. Савицька Г.В. Економічний аналіз діяльності підприємства: Навчальний посібник./ Г.В. Савицька. - К.: Знання, 2004. - 654 с.

8. Терещенко О. О. Контролінг у системі антикризового управління підприємством / О. О. Терещенко // Фінанси України. - 2001. - № 12. - С. 56-63.

9. Фатхудинов P.A. Конкурентоспособность: экономика, стратегия, управление./ Р.А. Фатхудинов. - М.: ИНФРА - М. 2000.-312 c.

10. Контролінг - від теорії до реалізації на практиці : моногр. / [кол. авт.: В. В. Прохорова, Л. С. Мартюшева, Н. Ю. Петрусевич, Ю. В. Прохорова]; Харківський національний економічний університет. - Харків: ІНЖЕК, 2006.$198 \mathrm{c}$.

11. Чобіток B.I. Управлінні потенціалом конкурентоспроможності промислових підприємств залізничного транспорту на засадах контролінгу : автореф. дис. канд. економ. наук : 08.00.04 - економіка та управління підприємствами (за видами економічної діяльності) / Вікторія Іванівна Чобіток. - X.: 2012. - 24 с.

УДК 330.65

\title{
ФОРМАЛІЗАЦІЯ ПІДХОДІВ ДО ДІАГНОСТИКИ РІВНЯ ФІНАНСОВОЇ БЕЗПЕКИ ПІДПРИЕМСТВ МАШИНОБУДУВАННЯ
}

\author{
Ус Ю.В., к.е.н., доцент (УІІА)
}

У статті визначені проблеми формалізачії підходів до діагностики рівня фінансової безпеки машинобудівних підприємств. Проведений аналіз складу чинників та рівня їх впливу на розвиток підприємств машинобудування в Україні. Визначені стратегічні напрями діяльності машинобудівних підприсмств України.

Ключові слова: фінансова безпека, рівень фінансової безпеки, діагностика, розвиток. 


\title{
ФОРМАЛИЗАЦИЯ ПОДХОДОВ К ДИАГНОСТИКЕ УРОВНЯ ФИНАНСОВОЙ БЕЗОПАСНОСТИ ПРЕДПРИЯТИЙ МАШИНОСТРОЕНИЯ
}

\author{
Ус Ю.В., к.э.н., доцент (УИПА)
}

В статье определены проблемы формализации подходов к диагностике уровня финансовой безопасности машиностроительных предприятий. Проведен анализ состава факторов и уровня их влияния на развитие предприятий машиностроения в Украине. Определены стратегические направления деятельности машиностроительных предприятий Украины.

Ключевые слова: финансовая безопасность, уровень финансовой безопасности, диагостика, развитие.

\section{FORMALIZATION OF APPROACHES TO DIAGNOSTICS OF LEVEL OF FINANCIAL SAFETY OF THE ENTERPRISES OF MECHANICAL ENGINEERING}

\author{
Us. U.V. candidate of economic science, docent
}

In article problems of formalization of approaches to diagnostics of level of financial safety of machinebuilding enterprises are defined. Financial safety of the enterprises of mechanical engineering consists in ability of the enterprise independently to develop and lead financial strategy according to the purposes of the general, corporate strategy, in the conditions of uncertainty and the competitive environment. It is carried out by means of administrative personnel of the enterprise.

The analysis of structure of factors and level of their influence on development of the enterprises of mechanical engineering in Ukraine is carried out. A significant amount of threats which concern functioning of a financial system of the enterprise demands improvement of mechanisms of ensuring its financial safety. Realization of this task is made at the expense of the analysis of external and internal threats, an assessment of consequences of their influence on financial activity of the enterprise and formation of a complex of administrative decisions which allow to increase the speed of its adaptive reaction to negative influence of environment.

Strategic activities of machine-building enterprises of Ukraine are defined. Need of continuous observance of financial safety it is caused objectively available for each subject of managing by a problem of ensuring stability of functioning and achievement of main goals of the activity. Level of financial safety of the enterprises of mechanical engineering depends on that, its management is how effective and will be capable to prevent possible threats and to liquidate harmful consequences of separate negative components of the external and internal environment.

Keywords: financial safety, level of financial safety, diagnostics, development.

Постановка проблеми та ї̈ зв'язки 3 науковими чи практичними завданнями. На сучасному етапі розвитку для економіки характерною рисою $є$ необхідність урахування підприємствами наслідків світової фінансової кризи. 3 огляду на це виникає необхідність постійного вдосконалення забезпечення їx фінансової безпеки та виявлення загроз, які можуть вплинути на іiі рівень. Фінансова безпека та використання інструментарію тактичного i стратегічного управління сприяє створенню передумов для якісних перетворень у діяльності підприємств та обумовлює своєчасне виявлення загроз у зовнішньому та внутрішньому середовищі. Особливої актуальності питання діагностики рівня фінансової безпеки набуває для підприємств машинобудівної галузі, що зумовлено іiі значною часткою у формуванні ВВП України.
Аналіз останніх досліджень $і$ публікацій. Проблема рівня фінансової безпеки на підприємстві розглядалась багатьма науковцями. Зокрема, П.А.Колпаков [1] виокремлює в якості базових нормативноправовий, системний, функціональний та синергетичний підходи діагностування рівня фінансової безпеки. Інші науковці виділяють: О.Нагірна [2] - інформаційний підхід, Ю.Б.Кракос, Р.О.Разгон [3]- ресурсний та програмно-цільовий підходи, О.Колісник [4] стаціонарний, динамічний та інституційний підходи.

Виділення невирішених частин загальної проблеми. Питання діагностики - одне 3 центральних питань економічної науки, оскільки стосується сутності та змісту управлінської діяльності. Аналіз функцій діагностики, їх чітка 
обгрунтована класифікація мають важливе значення для розробки наукових основ побудови системи управління, визначення іï структури i ступеня централізації і децентралізації. Доцільно зауважити, що сьогодні проблема діагностики рівня фінансової безпеки набула особливого значення, оскільки рівень спрацювання основних засобів промислового комплексу країни досяг критичної межі. У зв'язку 3 цим, актуальним постає питання формалізація підходів до діагностики рівня фінансової безпеки підприємств машинобудування, що на сьогодні не знайшло значного відображення у працях відомих вченихекономістів.

Постановка завдання. Мета дослідження полягає в систематизації та науково-теоретичній формалізації підходів до діагностики рівня фінансової безпеки підприємств машинобудування України; проведенні аналізу складу чинників та рівня їх впливу на розвиток підприємств машинобудування та визначення стратегічних напрямів їх діяльності.

\section{Виклад основного матеріалу}

дослідження. Для машинобудівних підприємств, що працюють в умовах конкуренції, можна виділити наступні види рівнів фінансової безпеки підприємства: підтримуючий, мінімальний, дуже низький, низький, середній, високий i дуже високий. Кількісна оцінка та характеристика кожного рівня фінансової безпеки підприємства наведені на рис. 1.

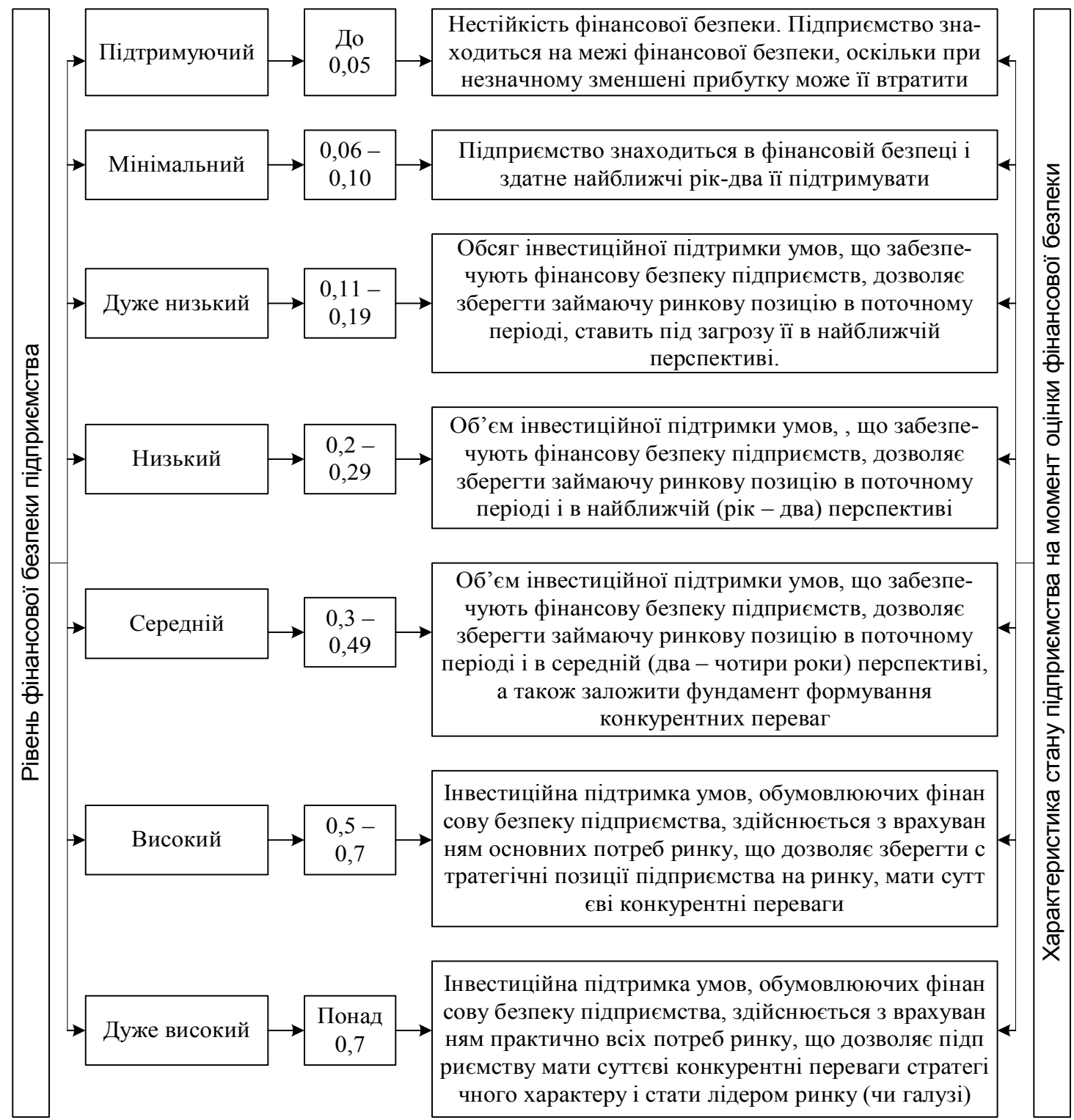

Рис. 1. Характеристика рівнів фінансової безпеки підприємства, діючого в умовах конкурениії 
Для забезпечення стабільності спроможні уникнути можливих загроз i функціонування підприємства та досягнення ліквідувати шкідливі наслідки окремих негативних головних цілей своєї діяльності виникає складових зовнішнього i внутрішнього необхідність постійного дотримання фінансової середовища. Аналіз загроз, які впливають на безпеки. Рівень фінансової безпеки підприємства фінансову безпеку підприємства представлені на залежить від того, наскільки ефективно іiі рис. 2. керівництво і спеціалісти (менеджери) будуть

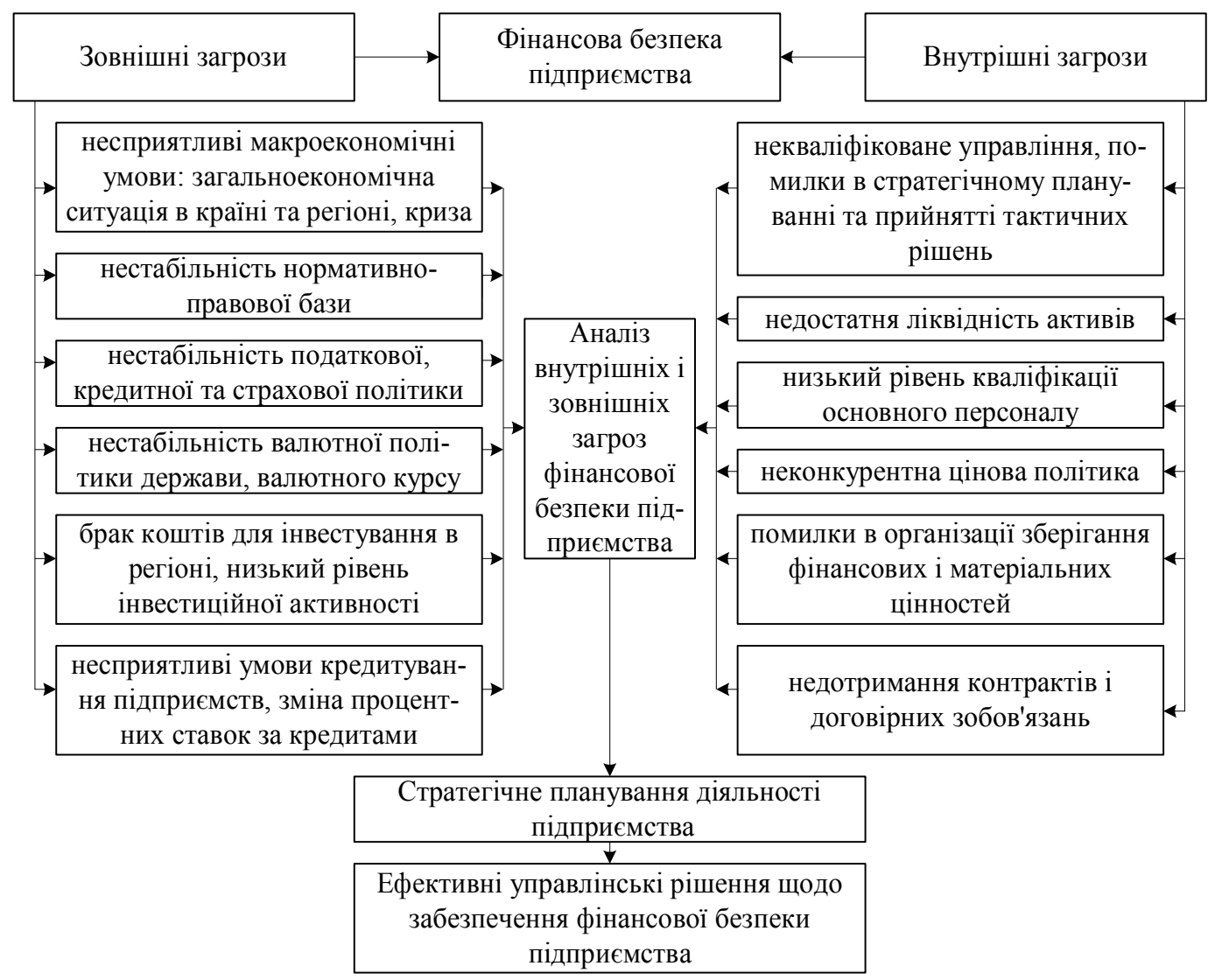

Рис. 2. Аналіз загроз, які впливають на фінансову безпеку підприємства

Питання, пов'язані 3 вибором та уніфікацією системи методів та показників діагностики рівня фінансової безпеки підприємства, набувають актуальності у кризових умовах розвитку економіки. Оскільки саме правильний вибір, послідовність та методика розрахунків, дозволить розробити ефективний механізм для якісного покращення фінансово-господарської діяльності підприємства.

Під діагностикою розуміється процес всебічного дослідження об'єкта з метою отримання висновку про його стан. В діагностиці рівня фінансової безпеки підприємства першорядна увага приділяється ефективності використання технічних, матеріальних і фінансових ресурсів, підвищенню продуктивності праці, прискоренню оборотності оборотних коштів, рентабельності виробництва. Тому діагностику рівня фінансової безпеки можна віднести до найважливішого засобу контролю виробничо-господарської діяльності підприємств і організацій. Існуючі методи та підходи діагностики дозволять гнучко реагувати на зміни зовнішнього та внутрішнього середовища, активно втручатися у хід виробничих процесів i постійно змінюваних господарських ситуацій, сприяти зменшенню ризику, пов'язаного 3 невизначеністю й вибором альтернативних рішень 3 управління господарськими ситуаціями, формування рекомендацій для прийняття зважених і адекватних управлінських рішень.

Інформаційний підхід діагностування рівня фінансової безпеки підприємств машинобудування передбачає забезпечення надійності інформаційної системи підприємства та збереження інформаційних ресурсів шляхом проведення спеціальних перевірок осіб, що допускаються до роботи 3 фінансовими документами та недопущення ऑii незаконного розповсюдженнях [2].

Проте на сучасному етапі розвитку ринкової економіки інформаційний підхід не має достатнього 
застосування, оскільки не ураховує всіх аспектів проблеми управління фінансовою безпекою.

3 позицій ресурсного підходу рівень фінансової безпеки визначається як стан корпоративних ресурсів (виробничих, фінансових, людських, інформаційних тощо) і підприємницьких можливостей, який забезпечує їх ефективне використання в поточному періоді та на перспективу 3 метою забезпечення розвитку підприємства [3].

Ресурсно-функціональниий підхід до діагностики рівня фінансової безпеки машинобудівного підприємства розглядається в наступних аспектах: забезпечення адаптації підприємства до змін ринкової кон'юнктури та якості реалізації управлінських функцій (планування, облік, аналіз).

На підставі застосування програмноцільового підходу фінансова безпека підприємств машинобудування передбачає формулювання проблемної ситуації; визначення цільової настанови управління фінансової безпеки (визначення мети, постановка завдань) та розробки програм реалізації сформульованої політики [3].

Офіційно визнаним підходом до діагностики рівня фінансової безпеки є стаціонарний підхід. В його межах фінансова безпека розглядається як стан об'єкта 3 точки зору його рівня, визначається незалежністю, стійкістю, стабільністю та потребує застосування інструментів фінансового менеджменту [4]. Проте можливості застосування такого підходу на практиці заперечують прихильники динамічного підходу, які вважають, що безпека $\epsilon$ сукупністю умов функціонування суб' єкта, що контролюється ним.

В практиці діагностування рівня фінансової безпеки машинобудівного підприємства значного розповсюдження набув також системний підхід. Саме цей підхід та особливості застосування інструментів та методів управління підприємством в фінансовій науці обумовили виокремлення в системі економічної безпеки підприємства іiі складових, зокрема фінансової безпеки [4]. За допомогою системного підходу будь-яка система безпеки розглядається як сукупність взаємозалежних елементів (підсистем), що має "вихід" (ціль - зниження рівня або попередження погроз), "вхід" (ресурси - фахівці, техніка й устаткування, механізми керування, фінансування), "процес" (практична робота із забезпечення безпеки - планування, організація, керування, взаємодія, підготовка й проведення конкретних заходів щодо протидії погрозам і ризикам), зв'язок iз зовнішнім середовищем, зворотній зв'язок. Таке визначення системного підходу до управління безпекою $є$ досить зрозумілим i формує чітке уявлення про механізм забезпечення фінансової безпеки підприємства.

Висновок. Таким чином, здійснивши формалізація підходів до діагностики рівня фінансової безпеки підприємств машинобудування можна сказати, що всі існуючі підходи потрібно детально аналізувати й потім приймати виважені управлінські рішення щодо впливу фінансової безпеки на загальний стан підприємств. Оскільки основними цілями фінансової безпеки машинобудівного підприємства $\epsilon$ : високоефективний менеджмент, технологічна незалежність i висока конкурентоспроможність, високий рівень кваліфікації персоналу, правове забезпечення всіх сторін фінансової діяльності, ефективне інформаційне забезпечення, захист комерційної таємниці, мінімізація негативного впливу на екологію, безпеку майна та капіталу. Саме визначення рівнів, цілей та загроз фінансової безпеки підприємств, діючих в умовах конкуренції, розраховано на їх захист від фінансової кризи, й забезпечення стратегічної стабільності функціонування.

\section{СПИСОК ЛІТЕРАТУРИ}

1. Колпаков П.А. Концептуальные основы экономической безопасности фирмы. - Автореф.дис. канд. экон. наук: 08.00.01 - М.: МГУ, 2007. - 24 с.

2. Нагірна О. Інформаційна та фінансова безпека компанії, або «рекрутинг чужими руками». Частина I // Практика управління. - 2007. - №8.- С.3840.

3. Кракос Ю.Б., Разгон Р.О. Управління фінансовою безпекою підприємств // Економіка та управління підприємствами машинобудівної галузі: проблеми теорії та практики. - 2008. - №1. - С.86-97.

4. Колісник О. Альтернативні підходи в теорії безпеки i ïx застосування у фінансовій науці [Електронний ресурс]. - Режим доступу:

http://www.library.tane.edu.ua/images/nauk_vydannya/KZ ITgn.pdf

5. Барановський О. I Фінансова безпека / Ін-т екон. прогнозування. - К.: Фенікс, 1999. - 338

6. Барановський O.I. Фінансова безпека в Україні (методологія оцінки та механізми забезпечення) / O.I. Барановський. - К.: Київ. Нац. Торг.-екон.ун-т, 2004. - 759c.

7. Шостак Л. В. Фінансово-економічна безпека підприємства / Л. В. Шостак, О. О. Помазун // вісник економіки транспорту і промисловості. - 2012. - № 38. - C. 144-146.

8. Сухоруков А.І. Фінансова безпека держави : навч. посібн. / А. І. Сухоруков, О. Д. Ладюк. - К. : Центр учбової літератури, 2007. - 192 с.

Рецензент д.е.н., професор УІПА Прохорова В.В. Експерт редакційної колехії к.е.н., дочент УкрДАЗТ Уткіна Ю.М. 